\title{
Formation of the Civil-Military Cooperation During the Settlement of the Armed Conflict in the South-East of Ukraine
}

\author{
Oleksandr Komisarov ${ }^{1}$, Ruslan Skrynkovskyy ${ }^{2}$, Serhii Bielai ${ }^{1}$, \\ Leontii Chystokletov ${ }^{3}$, Elvira Podoliak ${ }^{2}$, Oleksandra Khytra ${ }^{4}$ \\ ${ }^{1}$ National Academy of the National Guard of Ukraine \\ 7 Oborony Kyieva Street, Kyiv, 03179, Ukraine \\ ${ }^{2}$ Lviv University of Business and Law \\ 99 Kulparkivska Street, Lviv, 79021, Ukraine \\ ${ }^{3}$ Lviv Polytechnic National University \\ 12 Stepana Bandery Street, Lviv, 79013, Ukraine \\ ${ }^{4}$ Lviv State University of Internal Affairs \\ 26 Horodotska Street, Lviv, 79007, Ukraine
}

DOI: $10.22178 /$ pos.36-3

JEL Classification: K19

Received 20.06.2018

Accepted 20.07.2018

Published online 31.07.2018

Corresponding Author:

Leontii Chystokletov

chystokletov.leontii@tutanota.de

(C) 2018 The Authors. This article is licensed under a Creative Commons Attribution 4.0 License @ (1)

\begin{abstract}
This article considers the condition of ensuring national security of Ukraine in situations of the armed conflict in some areas of Luhansk and Donetsk regions. It proves the relevance of implementation of civil-military cooperation. The paper provides the analysis of the theoretical basis, tasks and functions of civil-military cooperation. The article explores activities of civil-military cooperation entities in Ukraine. It defines that the current situation in the South-East of Ukraine shows that tasks of monitoring and forecasting civil environment, forming recommendations regarding mutual influence of civil and military's acts have not been fully accomplished. The paper suggests using programmatic means of supporting decision making that were created on the basis of geoformation systems as a possible way of solving the problems.
\end{abstract}

Keywords: civil-military cooperation; the armed conflict; the antiterrorist operation; military units; law-enforcement bodies.

\section{INTRODUCTION}

The current difficult socio-political and military situation in Ukraine threatens its national security. The progress of the anti-terrorist operation in certain areas of Luhansk and Donetsk regions proves that statement. The armed conflict has caused significant losses of both personnel of military units and special law enforcement bodies of Ukraine, and civilian casualties among Ukrainians.

The issue of an armed conflict settlement requires integrated solution and the participation of a number of institutions and authorities to ensure the rule of law, protect the interests of the state and citizens, address severe consequences
[5], and in today's situation of globalization it requires involvement of both international humanitarian organizations and the security sector. [3]. Anti-terrorist operations in the South-East of Ukraine have revealed an absolute necessity to take into consideration social, political, cultural, religious, economic and humanitarian factors in the course of planning and conducting military operations. The strategic situation of the XXI century includes many ethnic, religious, ideological movers that require sustainable solutions in societies undermined by conflicts, natural or humanitarian disasters. In order to resolve these serious problems, it is impossible to use only military means. 
According to most experts and modern requirements of the international humanitarian law, under such conditions, Ukraine cannot settle the armed conflict without civil-military cooperation (CIMIC).

The literature of recent years analyzes some issues concerning modern armed conflicts inside a state, namely the works of such scholars as V. Averyanov, O. Bandurka, O. Baldynyuk, S. Bilotskyy, V. Vakulych, M. Hutsman, D. Dubov, V. Dyachenko, N. Zielinska, Y. Ivanov, V. Lysyk, M. Pendyur, O. Pulym, etc.

The issue of civil-military relations in situations of armed conflict is discussed in the works of the following scholars: A. de Ruiter, L. Ebling, J. Eisenhower, E. Marks, L. Elbadawi, C. Gibson, D. Snider, W. Gregor, S. Kaufmann, C. King, R. Kohn, J. London, R. Hayes, L. Minear, C. Scott, T. Weiss, E. Stepanova, etc.

However, there has not been done enough to research the role and place of CIMIC regarding internal armed conflict settlement.

The article aims to analyze the main idea of CIMIC regarding the settlement of armed conflicts. It also shows the current condition of its implementation during the anti-terrorist operation in South-Eastern Ukraine.

\section{RESULTS AND DISCUSSION}

The CIMIC as a military function is an inalienable part of many modern multidimensional operations. It requires all the parts to cooperate in a conflict situation and eases mutual support of civil and military forces and vice versa. The main idea of this cooperation is to achieve certain and usually the desired end results to improve the cooperation with local population, civil people. At present, military operations take place within larger political and civil context than before. Therefore governing bodies more often have to consider social, political, cultural, religious, economic, environmental and human factors in the process of planning and conducting special operations. The scope, nature, risks and challenges in this multi-ethnic, multi-agent environments require more understanding and emphasizing CIMIC at all levels.

Military operation planning requires the use of CIMIC, which allows all the other military units to work within and beyond the area of service and combat missions. Numerous parameters of mod- ern military operations are influenced by CIMIC as they are focused on civil environment [4].

The aim and purpose of CIMIC are interaction between military and civilian figures within an integrated environment to maintain military command plan. Ideally, all participants will work to achieve a common goal, but where impossible, the interaction will ensure that measures to maintain each plan are as agreed as it is possible. This will minimize the interference or unintended conflict between all parties. This interaction may have the following components: coordination; cooperation; mutual support; coherent common planning; exchange of information [2].

The operational environment in a crisis situation is likely to always be difficult, unstable and unpredictable. Short-term success may undermine the medium- and long-term prospects by destruction of traditional cultural foundations of local civilians. In this regard, CIMIC units play a vital role as one of the main advisers to government bodies and perform the following service and combat missions:

1) establishing and maintaining communication with civil population at an appropriate level, promoting cooperation, harmonization, information exchange, providing comprehensive planning and conducting operations;

2) defining and explaining military goals, tasks and concept of operations (to provide proper security and control of operations with classified materials);

3) promoting parallel and, where possible, integrated planning between military forces and friendly civilian population (when civic groups' participation in planning is possible);

4) carrying out integration with other types of personnel in all aspects of activities;

5) continuously evaluating the operating environment, including local needs and inequal opportunities to solve problems;

6) operating towards the timely and smooth transfer of responsibilities to appropriate civil authorities.

Depending on circumstances, management of military forces and law enforcement bodies may require significant support from civilian population to coordinate efforts and minimize disruption of a special operation. For this reason, CIMIC plays an active role, it contributes to operation planning and is involved in these operations. 
Such activities in collaboration with other service and combat features include:

1) obtaining timely information about the social component (civil environment) of a crisis situation;

2) analyzing information and formulating holistic description of a crisis situation;

3) assessing a crisis situation, determining key civil indicators and factors that have a decisive impact on the operations and an impact of a military situation on the civilian environment;

4) providing recommendations during operation planning to mitigate the military impact on the civilian population;

5) using CIMIC in operation planning;

6) inviting forces;

7) ensuring a favorable impact on the public within the area of service and combat missions;

8) providing access to civilian resources when it is necessary.

Based on the experience of Canada, the Netherlands, and Denmark, the departments of CIMIC have been established in the Armed Forces of Ukraine.

According to the legal framework of Ukraine, CIMIC is "systematic, planned activities - of the Armed Forces of Ukraine and other military formations and law enforcement bodies established according to the laws of Ukraine (hereinafter the Armed Forces of Ukraine) - to coordinate and cooperate with executive authorities, local au- thorities, public associations, organizations and citizens in the deployment areas of military units of the Ukrainian Armed Forces, in order to form a positive public opinion and provide favorable conditions for the implementation by the Ukrainian Armed Forces of their tasks and functions by assisting the civilian population in solving their daily problems with the use of military and nonmilitary forces and measures" [1].

Today, 14 groups and two combined centres of CIMIC work in the area of conflict in the towns of Mariupol and Severodonetsk. Subsequently, the number of specialists is going to be increased. The Ukrainian Defense Ministry Representatives note that if the current relevant groups of CIMIC are in each operational command, each brigade command is going to be provided with such experts [8].

The main tasks of CIMIC units of Ukraine are to organize cooperation with local authorities, international and non-governmental organizations, civilians and others. It could therefore be concluded that these units play the leading role in organizing interaction of the Anti-Terrorist Center of Ukraine with the civil sector in the area of counterterrorism operations. Figure 1 shows the structure of the interaction of the CIMIC in the area of anti-terrorist operation.

It should be noted that linkages among the elements of figure 1 generally show the areas of interaction and are not "fixed", therefore despite designations in the figure any element of the block diagram can interact with the others.

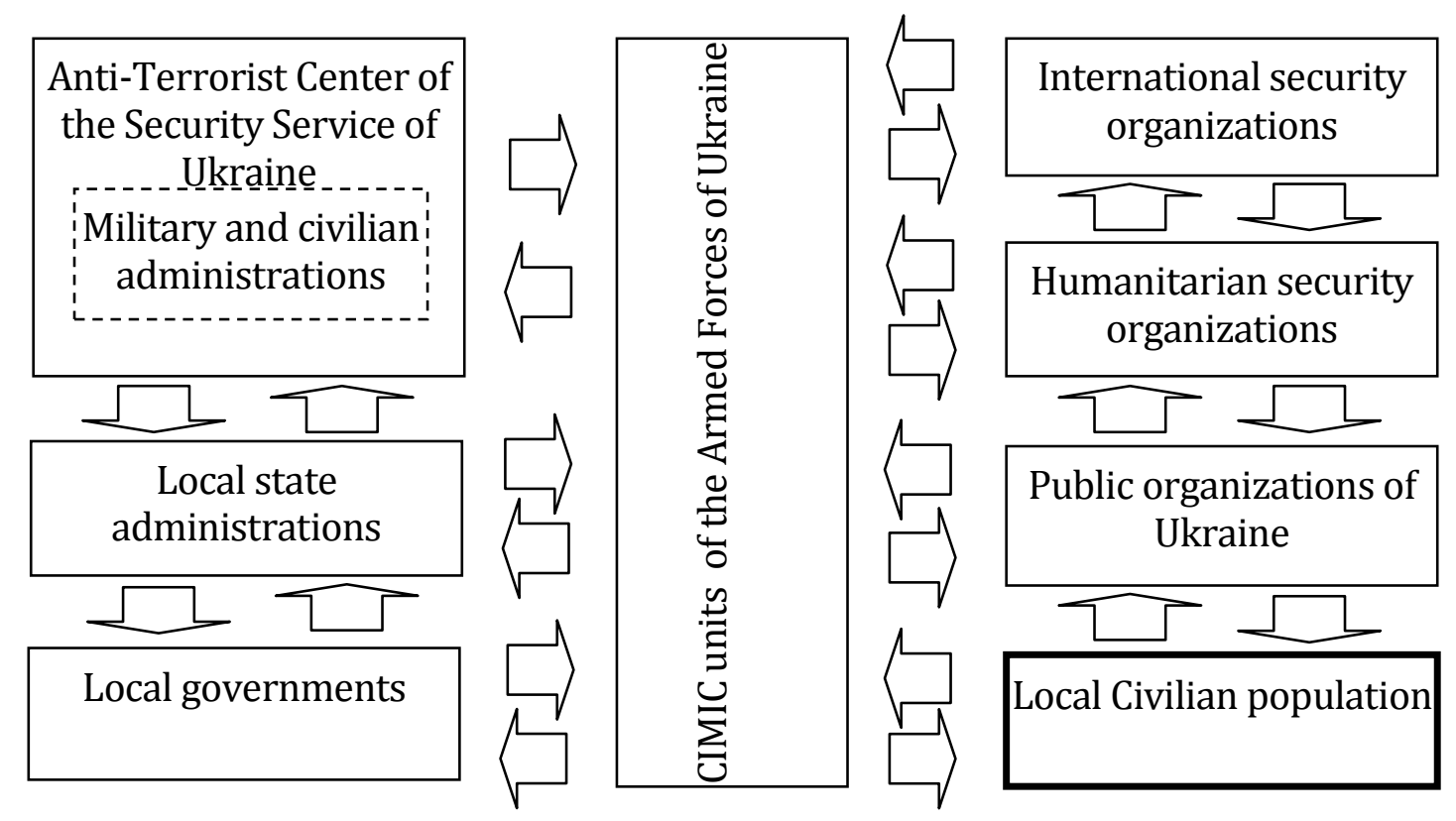

Figure 1 - The block diagram of the interaction between the departments of CIMIC in the area of anti-terrorist operation 
The left column of Figure 1 contains governing bodies operating in the area of anti-terrorist operation. The Anti-Terrorist Centre is a permanent body at the Security Service of Ukraine that conducts the coordination of anti-terrorism personnel to prevent terrorist attacks against state officials, critical life support sites, high danger sites as well as prevention and liquidation of the activities that threaten life and health of significant numbers of people [8].

The Anti-Terrorist Centre comprises military and civilian administrations that are created as a temporary forced means with elements of military government organization to provide civil security and create conditions for the normalization of life of the population in the territories where the anti-terrorist operation is being conducted, and are not meant to change and/or cancel the constitutional right of local communities to have self-government [7].

Military and civilian administrations are not formed in all districts of Luhansk and Donetsk regions; therefore they are dotted in figure 1 . Thus, local state administrations and local governments also operate in the area of the antiterrorist operation.

The right column of fig. 1 shows the international factor and the public sector operating in the antiterrorist operation area, which are aimed at settling the armed conflict.

First and foremost, it is the OSCE Special Monitoring Mission that refers to international organizations of security sector in the area of antiterrorist operation. Today the unarmed civil OSCE Special Monitoring Mission is virtually the only support among the security international organizations in the settlement of the armed conflict on South-Eastern Ukraine (besides the economic sanctions against the aggressor country [15]). The OSCE Special Monitoring Mission to Ukraine was deployed on 21 March 2014, following the request to the OSCE by Ukraine's government and a consensus decision by all 57 OSCE participating states [9]. The main tasks of the Special Monitoring Mission are to observe and report impartially and objectively on the situation in Ukraine as well as to facilitate the dialogue among all parties to the conflict. It consists of about 250 unarmed civilian observers from OSCE participating states, with support provided by the Ukrainian personnel. The OSCE mandate was also given to the small OSCE Observer Mission at the Russian Checkpoints Gukovo and Donetsk, following the request by the government of Russia; the decision was made by consensus of all 57 OSCE participating states. The OSCE Observer Mission at the Russian Checkpoints Gukovo and Donetsk has been operating since 29 July 2014 in accordance with the consensus decision of the OSCE Permanent Council [10]. According to the mandate of the Observer Mission, the observers monitor the situation and the movements across the border at the two Russian checkpoints, and report on that. The Observer Mission consists of 21 civilian observers including the Chief Observer.

Among many others, the Red Cross is a major humanitarian international organization in the area of the anti-terrorist operation. The International Committee of the Red Cross (ICRC) is an independent humanitarian organization aimed to protect victims of international and internal armed conflicts. During the international and internal armed conflicts the ICRC provides protection and aid for both military and civilian victims (in particular war prisoners, interned civilians, wounded, civilians in the occupied territories etc). A priority in the relations between the ICRC and Ukraine is given to cooperation between the Committee and the Ukrainian Red Cross Society to provide aid for people affected by the conflict in the South-East of Ukraine. At present the ICRC has opened six offices in our country - in Kharkiv, Donetsk, Luhansk, Severodonetsk, Mariupol and Odesa. The organization is actively involved in the mobilization of resources for the affected areas; particularly, the ICRC aid is given to the Ukrainian families, displaced people and hospitals, namely materials for the housing repairs (glass, concrete, roofing materials), food, warm clothing, medical supplies, drugs, etc. [11].

Quite a few Ukrainian public organizations operate in the anti-terrorist operation area. These include voluntary organizations that were the first to support military units and law-enforcement bodies of Ukraine and are still providing them with help. For instance, Fundatsia.101, a nongovernmental organization, has carried out the project called Frontline Inspection. The project has been supported by People's Project, the Ukrainian Parliament Commissioner for Human Rights and the military and civilian administration of Donetsk region. The main task of this initiative is to monitor entry and exit checkpoints on the contact line in Donetsk region and determine whether the state authorities are fulfilling 
CTemporary control procedure over the movement of individuals, vehicles and cargo (goods) through the contact line within Donetsk and Luhansk regions. The goal of the project is to ensure the observance of human rights during the crossing procedure, to simplify it for Ukrainian citizens and to curb corruption in crossing the contact line in Donetsk and Luhansk regions [14].

The most important and the main element of fig. 1 is local civilian population. The aim of the CIMIC is to establish and maximize cooperation between civilians and military structures within the area of the conflict. Today the factors of international humanitarian law and respect for civilians play the crucial role, impose substantial restrictions towards the methods of using troops and encourage solving most tasks without the use of force or threat of force, only by coordination of the military command and civilian population [6]. Therefore figure 1 shows local civilian population in bold.

Based on figure 1 and previous experience it can be noted that there are some problem issues relating to the activity of CIMIC units. The bodies of CIMIC according to the NATO standards should draw up an appropriate plan, based on the detailed monitoring of social environment and providing appropriate measures. Along with it, CIMIC units have to provide the command with forecasts and advice on the mutual influence of actions of the civilian and military parties to the conflict. In addition, the abovementioned units shall prepare information for military leadership on changes in the social environment. The current situation in South-Eastern Ukraine shows that the listed tasks are not being performed completely.

To date, there are already a number of decisionmaking software tools that can be applied to solve the abovementioned tasks. Modern decision-making software tools are developed on the basis of Geographic Information Systems (GIS) which provide classical statistical analysis and forecasting methods with modern technologies of collection, processing and application of spatial data on the electronic maps [13]. In this case, when events are connected with the map coordinates, it becomes possible to do the following: to group objects in a cluster around certain regions, cities, blocks, depending on the scale of the map; to search the spatial connections between events related to a particular type of action in accordance with the classifications and the content of spatial object attributes; to use the geospatial technologies for requests to make groups of objects, to obtain their coordinates, to apply them on the electronic map and to edit their attributes; to calculate the long-term and short-term forecasts of crisis situations, the statistics of event breakdown in a particular area and display them on the map as diagrams [12].

With regard to the considered tasks of the CIMIC units, it is extremely essential to use the decisionmaking software tools developed on the basis of GIS.

Thus, to solve the listed issues, CIMIC units should carry out these main tasks:

- to organize and to carry out cooperation with all stakeholders and civilians on the territories controlled by military units and law enforcement bodies of Ukraine (as various forums and meetings with heads of international organizations or other joint activities, their media coverage);

- to coordinate cooperation of military units and law enforcement bodies of Ukraine, international and public organizations in providing aid for the population that has suffered from the armed conflict and the activities of terrorist groups;

- to brief the military leadership on changes in the social environment;

- to provide advice on the mutual influence of the civilian and military parties to the conflict.

\section{CONCLUSIONS}

1. The anti-terrorist operation in the South-East of Ukraine has made it necessary to take into account social, political, cultural, religious, humanitarian and economic factors while planning and carrying out military actions. Under such conditions, according to most experts and international humanitarian law, the armed conflict in Ukraine cannot be settled without CIMIC.

2. Relying on the experience of Canada, the Netherlands and Denmark, CIMIC units have been established within the Armed Forces of Ukraine for the purpose of coordination and interaction between the Armed Forces of Ukraine and the executive bodies, local government, public associations, public organizations and citizens. These units play the leading role in organizing cooperation between the Anti-Terrorist Centre and civil sector in the anti-terrorist operation area. 
3. The structure of the interaction between the CIMIC units which is used in this article clearly reveals and allows to evaluate the process of organizing the interaction between these units and governing bodies, international organizations and public sector in the area of the anti-terrorist operation.

4. At present, there are some challenges relating to the activity of CIMIC units. They refer to monitoring and forecasting the social environment, making recommendations on the mutual influence of actions of the civilian and military parties to the conflict, etc. The current situation in the South-East of Ukraine shows that the assigned tasks are not being performed completely. One of the solutions to these problems is using the decision-making software tools created on the basis of GIS.

5. Further research will be aimed at creating mechanisms to improve the performance of the CIMIC units as well as developing appropriate decision-making software tools created on the basis of GIS of the National Guard of Ukraine.

\section{REFERENCES}

1. Armed Forces of Ukraine. (n. d.). Civil-military cooperation. Retrieved June 1, 2018, from https://cimic.com.ua/en

2. Civil-Military Cooperation of Excellence. (2016). Cimic Field Handbook (4th ed.). Retrieved from https://library.cimic-coe.org/cimic-field-handbook-4th-edition

3. Endrijaitis, R., \& Alonderis, A. (2015). Security facets: complex dynamic systems and leadership in military. Journal of Security and Sustainability Issues, 4(4), 299-309. doi: 10.9770/jssi.2015.4.4(0)

4. Evtushenko, I. (2015). Modern war conflict: the consequences of international terrorism on the base of globalization (theoretical and legal aspect). Authority and society (History, Theory, Practice), 4(36), 156-157.

5. Lankauskienè, T., \& Tvaronavičienè, M. (2012). Security and sustainable development: approaches and dimensions in the globalization context. Journal of Security and Sustainability Issues, 1(4), 287-297. doi: 10.9770/jssi.2012.1.4(5)

6. NATO. (2003). NATO Civil-Military Cooperation (Cimic) Doctrine. Retrieved from https://www.nato.int/ims/docu/ajp-9.pdf

7. On Civil-Military Administration (Ukraine), 3 February 2015, No 141-VIII. Retrieved June 1, 2018, from http://zakon4.rada.gov.ua/laws/show/141-19

8. On the Regulation of Anti-Terrorist Centre and its Coordinating Groups at the Regional Security Service of Ukraine (Ukraine), 14 May 1999, No 379/99. Retrieved June 1, 2018, from http://zakon4.rada.gov.ua/laws/show/379/99

9. OSCE. (n. d.). Special Monitoring Mission to Ukraine. Retrieved June 1, 2018, from https://www.osce.org/special-monitoring-mission-to-ukraine

10. OSCE. (n.d.). Observer Mission at the Russian Checkpoints Gukovo and Donetsk. Retrieved June 1, 2018, fromhttps://www.osce.org/observer-mission-at-russian-checkpoints-gukovo-anddonetsk

11. Permanent Mission of Ukraine to the UNO Branch and other International Organizations in Geneva. (2017). International Committee of the Red Cross. Retrieved from http://geneva.mfa.gov.ua/ua/ukraine-io/red-cross

12. Sahoo, P. M. (2009). Statistical techniques for spatial analysis. Retrieved from http://www.iasri.res.in/ebook/EBADAT/6-Other\%20Useful\%20Techniques/11Spatial\%20STATISTICAL\%20TECHNIQUES.pdf

13. Talhofer, V., Hošková-Mayerová, Š., \& Hofmann, A. (2016). Towards efficient use of resources in military: methods for evaluation routes in open terrain. Journal of Security and Sustainability Issues, 6(1), 53-70. doi: 10.9770/jssi.2016.6.1(4) 
14. Ukrainian Volunteers Center. (2017). Front-line Inspection. Retrieved June 1, 2018, from http://www.peoplesproject.com/prifrontova-inspekciya

15. Veebel, V. (2016). Will sanctions against russia be successful: will russia fall before Ukraine? Journal of Security and Sustainability Issues, 5(4), 465-480. doi: 10.9770/jssi.2016.5.4(2) 